LANKESTERIANA 6(2): 73-81. 2006.

\title{
THREE NEW SPECIES OF MARCGRAVIACEAE FROM COSTA RICA, WITH REFERENCES TO RELATED SPECIES AND NOTES ON THE GENERIC PLACEMENT OF SCHWARTZIA JIMENEZII
}

\author{
BARRY E. HAMMEL \\ Missouri Botanical Garden, P.O. Box 299, St. Louis, Missouri 63166, USA \\ Instituto Nacional de Biodiversidad (INBio), apdo. 22-3100, Santo Domingo, Heredia, Costa Rica.
}

ABStRACt. Marcgravia glandulosomarginata, Ruyschia moralesii and Schwartzia tarrazuensis, woody epiphytes known mostly from mid-elevation rainforest of Costa Rica's pacific coastal mountains just south of San José, are described, compared to related species and illustrated. The new Marcgravia species is known also from Panama and Colombia, but the other two species are endemic to Costa Rica.

Resumen. Se describen, ilustran y comparan con especies afines Marcgravia glanduloso-marginata, Ruyschia moralesii y Schwartzia tarrazuensis, epífitas leñosas principalmente de bosques lluviosos de alturas medias en la cordillera costeña pacífica de Costa Rica, al sur de San José. La nueva especie de Marcgravia se conoce también de Panamá y Colombia; las otras dos especies son endémicas en Costa Rica.

Key words / Palabras clave: Marcgraviaceae, Marcgravia, Ruyschia, Schwartzia, Costa Rica, Panama, Colombia.

During the preparation of the Marcgraviaceae treatment for the Manual de Plantas de Costa Rica, three new species for the family have come to light. All of them are woody epiphytes, and are known from and can even be found locally sympatric in, though not all are restricted to, the botanically rich pacific coastal range just south of San José, along the border between San José and Puntarenas provinces. The elevational range within which these species occur [(700) 900$1800 \mathrm{~m}$ ] encompasses that generally cited as highest in diversity, especially for epiphytes (see Gentry \& Dodson 1987, Zamora et al. 2004: 195-216). Other epiphytic or climbing species that have recently been described from this specific region of Costa Rica include: Apocynaceae - Allomarkgrafia insignis J.F. Morales, Araceae - Philodendron dominicalense Croat \& Grayum, Asclepiadaceae - Matelea costaricensis W.D. Stevens, Bromeliaceae - Werauhia tiquirensis (J.F. Morales) J.F. Morales, Cactaceae - Weberocereus frohningiorum Ralf Bauer, Gesneriaceae -Paradrymonia bullata Gómez-Laur. \& M.M. Chavarría (= Nautilocalyx biserrulatus Kriebel), Orchidaceae - Kefersteinia orbicularis Pupulin, Macroclinium confertum Pupulin, Ornithocephalus castelfrancoi Pupulin. New country records or rediscoveries of rare epiphytic or climbing species also from this area include: Asclepiadaceae - Marsdenia laxiflora Donn. Sm., Gesneriaceae - Drymonia peltata (Oliv.) H.E. Moore, Lomariopsidaceae - Elaphoglossum moralesii A. Rojas, Malpighiaceae - Stigmaphyllon bogotense Triana \& Planch.,
Orchidaceae - Catasetum integerrimum Hook.

The very diverse morphology of the nectariferous inflorescence bracts, as well as the very strong and unusual (fruity to rumlike, pers. obs.) floral fragrances in many species, should make this family fertile ground for a study of pollination and floral biology. As pointed out by Ward \& Price (2005), few such studies have been made but known pollinators include bats and birds (see Dressler \& Tschapka 2002), and oddly, cleistogamy. The presence of oil-bearing pollen, observed on live material of two of the species described below, as well as on herbarium specimens of several other species in different genera of Marcgraviaceae, appears not to have been mentioned previously in the literature.

\section{Marcgravia glandulosomarginata Hammel, sp. nova}

Haec species nova Marcgravia schippii similis, sed imprimis differt sepalorum glandulis obscuris glandulisque poriformibus submarginaliter lineatis (ad vicem inornatis), etiam laminarum foliorum glandulis obscuris, submarginalibus, conspicuoribus lineatis quasi a basi ad apicem complectentibus.

[This species is similar to M. schippii, but differs principally by its sepals with submarginal rows of dark glands and poriform glands and by its leaf blades with a more conspicuous submarginal row of dark glands extending from nearer the base to the tip] 
TYPE: Costa Rica; San José, cantón de Tarrazú, entre Cerro Toro y Cerro Hormiguero, $c a .15 \mathrm{~km}$ al suroeste de San Marcos, camino a Quepos, 1100 m, 14 jul 2005 (fl, fr), Hammel et al. 23714 (holotype: INB, isotypes: COL, CR, FR, MICH, MO, P). Figs. 1, 4A.

Woody liana; fertile branches terete, drying tan to light grayish tan, sometimes exfoliating, with lines of darker, \pm conspicuous lenticels to $1.5 \times 0.7 \mathrm{~mm}$. Mature leaves indistinctly petiolate, the petiolar region to only $c a$. $1 \mathrm{~mm}, \pm$ flattened above, rounded below; blade 10.5-13 $\times(2.5-) 3-5 \mathrm{~cm}$, oblong-elliptic, drying grayish to orangish tan, usually lighter or more orangecolored below, the base often slightly asymmetrical, abruptly obtuse to rounded, rarely acute, the apex acute to broadly acuminate; secondary veins indistinct; hypophyllous glands in two distinct rows on each side of the midrib, the submarginal of dark, solid, circular to ovate dots running from a few $\mathrm{mm}$ of the midrib at base to a few mm of the tip, the laminar of 4-8(-14), mostly narrowly elliptic, poriform glands in a diagonal line from the base of the midrib towards the margin at about midleaf. Inflorescence erect, the peduncle 0.3$1 \mathrm{~cm}$ with 5-9 flowers and 1 nectary, the rachis 2-4 $\mathrm{mm}$, shortly conical; pedicels $4.5-6 \mathrm{~cm}$, ascending at mostly $<45^{\circ}$, conspicuously lenticellate, the lenticels to $c a .2 \mathrm{~mm}$ in diam. and often 4-lobed, the epidermis drying light grayish tan, often transversely splitting, exfoliating. Nectary 1, erect, green to dark greenish purple, lenticellate as on the flower pedicels, the free pedicel 5-8 mm, the cup 35-50 mm, tubular, clavate, basally flanged to spurred, the spur $2-5 \mathrm{~mm}$, apically sometimes with a small (to $6 \mathrm{~mm}$ ) bud. Flower buds green, erect 13-18(-20) mm, conical with an acute- to obtusely rounded apex, the 2 bracteoles to $3.5 \mathrm{x} 4 \mathrm{~mm}$, semicircular to broadly ovate, born $c a .2 \mathrm{~mm}$ below the calyx, usually minute or lacking; sepals appressed, \pm equal (the outer 2 slightly wider than the inner 2), ca. $7 \times 11 \mathrm{~mm}$, broadly semicircular, thin-margined with a continous submarginal row of conspicuous, dark glandular dots, and just inward of them, at the lower edges and sometimes nearly continuous, an additional row of few to many poriform glands; corolla calyptrate (see flower buds above). Stamens 34-44, prior to anthesis the filaments $4-5.5 \mathrm{~mm}$, flattened, the anthers (3-)5-7.5 mm, oblong-linear, basally sagittate, apically retuse, releasing pollen in bud. Ovary ca. $8 \mathrm{~mm}, \pm$ obturbinate, 9-loculate. Fruits 12-18 mm, slightly depressed globose, the sepals spreading.

Distribution. This somewhat rare and overlooked species is known from Costa Rica to Colombia in rain forest at (700-) 900-1750 m elevation.

Eтymology. The epithet glandulosomarginata refers to the distinctive rows of dark and poriform glands on the margins of the sepals and the submarginal row of dark glands along nearly the entire length of the leaf blade.

Discussion. This species is distinct for its submarginal rows of dark glands and poriform glands on the sepals, for its very obvious submarginal row of dark glands running from very near (1-5 mm from) the base to very near the tip of the leaf, and for the light grayish tan, transversely splitting and exfoliating epidermis of the pedicels. It somewhat resembles M. brownei (Triana \& Planch.) Krug \& Urb. in leaf size and shape, and the diagonal row of \pm numerous poriform hypophyllous glands, but in addition to the first stated characters, differs from that species by having fewer flowers and nectaries, and the pedicels ascending rather than at a right angle or reflexed. However, overall, the new species is more like M. schippii Standl., with which it has been confused and with which it agrees in most aspects, including that of having only one nectary per inflorescence. In addition to the first stated characters, it differs from M. schippii by having usually 4-8 or more instead of only 1-4 poriform hypophyllous glands on each side of the midrib. The submarginal hypophyllous glands of $M$. schippii are relatively pale, visible beginning no closer than $12 \mathrm{~mm}$ from the base of the blade, and are sometimes accompanied by a few somewhat poriform glands. Flowering pedicels of most material of $M$. glandulosomarginata lack bracteoles, whereas they are always present on $M$. schippii. These two species are somewhat separated elevationally, M. schippii known mostly from sea level to below $1000 \mathrm{~m}$, and the new species not known from below $700 \mathrm{~m}$, is found mostly between $1000-1750 \mathrm{~m}$. The Colombian material included here has up to 14 hypophyllous glands in the diagonal row, whereas in Costa Rica, the most seen was eight.

Additional specimens. COSTA RICA. Heredia: Cantón de Sarapiquí, Parque Nacional Braulio Carrillo, 1060 m, 29 Nov 1992 (st), Boyle 1324 (MO); John \& Kathy Utley 5632 (DUKE, MO). San José: Cantón de Pérez Zeledón, Fila Tinamastes, 1140 m, 14 Febr 1996 (fr), Hammel et al. 20205 (INB, MO); cantón de Tarrazú, entre Nápoles y Santa Marta, 1400 m, 5 ago 1994 (fl), O. Vargas 460 (INB, MO); 1360 m, 5 Aug 2005 (fl, fr) Hammel \& Pérez 23760 (CR, INB, MO); 13 Jan 2006 (fl, fr), Hammel et al. 24043 (CR, INB, F, MO); 1100 m, 17 Febr 2006 (fl, fr), Hammel et al. 
24114 (FR, INB, MO). PANAMA. Chiriquí: 1000 m, 2 Aug 1984 (fl), Churchill 5919 (MO). Coclé: 930 m, 6 Dec 1979 (fr), Croat 49214 (MO); 700-750 m, 27 Nov 1985 (fr), McPherson 7685 (MO). COLOMBIA. Antioquia: Urrao, Las Orquídeas, 890 m, 1 abr 1988 (fr), Cogollo et al. 2903 (JAUM, MO); 1450 m, 18 oct 1993 (fl), Cogollo et al. 7066 (JAUM, MO); 1450 m, 5 dic 1993 (fl, fr), Cogollo et al. 7819 (MO); 1750 m, 24 Sept 1987 (fr), Zarucchi et al. 5722 (MO).

\section{Ruyschia moralesii Hammel, sp. nova}

Haec species nova Ruyschia andina cum floribus quinquestaminatis et ovario triloculari valde similis, sed imprimis differt laminis foliorum notabile angustioribus, tenerioribus, glandulis hypophyllis minus conspicuibus sed magis numerosis, area latiore in utroque costae lato dispersis.

[This species is most similar to $R$. andina for its flowers with 5 stamens and a 3-locular ovary, but differs from it principally by its distinctly narrower and much less coriaceous leaves with less conspicuous but more numerous hypophyllous glands spread in a wider area on each side of the midrib.]

TYPE: Costa Rica; San José, Cantón de Tarrazú, ca. 19 km de San Marcos, camino a Quepos por Londres, 17 febr 2006 (fl) Hammel et al. 24095 (holotype: INB, isotypes: CR, FR, MICH, MO, P, QCA). Figs. 2, 4B.

Shrubby epiphyte or woody liana. Leaves with a definite petiole $0.5-1 \mathrm{~cm}$, slightly flattened above; blade 7.5-10 × 3-3.5 cm, oblanceolate, drying dark tan to nearly black, the base \pm symmetrical, cuneate, the apex acute to obtuse, mucronate, sometimes retuse; secondary veins obscure on both surfaces, slightly more evident below; hypophyllous glands inconspicuous, 16-40 (on each side of the midrib), poriform, more or less scattered the length of the blade in a broad band between the margin to $c a$. halfway to the midrib. Inflorescence an erect raceme, 6-21 cm (including the peduncle) with 25-70 flowers; pedicels 5-10 mm patent at anthesis, lacking lenticels. Nectaries green, attached 1.5-2.5 $\mathrm{mm}$ below the flower, ca. $6 \mathrm{~mm}, \pm$ spoon shaped with a narrow stalk (ca. $2 \mathrm{~mm})$ and an orbicular, abaxially concave lamina $(c a .4 \mathrm{~mm})$ with 2 hypophyllous, poriform glands. Mature flower buds 5-6 mm, globose-ovoid, the 2 bracteoles sepaloid, $c a$. $1.5 \times 2 \mathrm{~mm}$, broadly semicircular, born just below and appressed to the sepals; sepals \pm equal, $c a .2 .5 \mathrm{x}$ $3 \mathrm{~mm}$, broadly semicircular; corolla green, the petals
5 , basally connate to about the level of the sepals, the lobes reflexed, 4-5 x 3.5-4 mm, ovoid. Stamens 5, the filaments green, 3-4 mm, narrowly triangular-flattened, the anthers orangish yellow, 1.5-1.7 x ca. $1 \mathrm{~mm}, \pm$ triangular, basally sagittate, apically obtuse, the pollen orangish yellow, apparently mixed with oil. Ovary ca. $4 \mathrm{~mm}$ (including the $c a .1 \mathrm{~mm}$ style), \pm bottle-shaped, 3 -locular, the stigma indistinctly lobed. Fruits greenish pink, $c a .8 \mathrm{~mm}$ (including the $c a .2 \mathrm{~mm}$ stylar beak), globose-ovoid.

Distribution. This species is known only from Costa Rica, along the central pacific slope in coastal mountains towards the northern end of the Talamanca cordillera in rain forest between 1100-1800 m elevation.

Etymology. This species is dedicated to friend and colleague, Juan Francisco Morales, instrumental in the discovery of this and hundreds of other new species and new records for Costa Rica, especially from his favorite haunts in the Acosta region, along the Pacific slope, just south of San José.

Discussion. Among Costa Rican species, $R$. moralesii resembles the rare $R$. enervia Lundell for its five stamens, but it differs markedly from that species by having more numerous hypophyllous glands (to only ca. 7 in $R$. enervia), nectariferous bracts having a stalk, rather than being sessile, and arising somewhat distant from the flowers rather than virtually adjacent to them, smaller flowers, and a 3- (rather than 2-) locular ovary. Only one other species currently placed in Ruyschia, the recently described, South American $R$. andina de Roon (de Roon 2005) has a 3-locular ovary. This new Costa Rican species is most probably sister to $R$. andina, differing from it most obviously by its distinctly narrower and much less coriaceous leaves with less conspicuous but more numerous hypophyllous glands spread in a band, rather than a distinct line. It also appears to have the nectaries placed more distant from the flowers, and somewhat smaller inflorescences. Otherwise, the distinctly petiolate leaves, the shape and position (somewhat distant from the flower) of the nectariferous glands, flower size and number of stamens are the same as or similar to $R$. andina. Ruyschia andina is known from 1800-2300 m elevation in rain and cloud forest on the eastern slopes of the Andes of Ecuador, Perú and Bolivia.

The similarity of Ruyschia moralesii and R. andina to another Marcgraviaceae endemic to Costa Rica, Schwartzia jimenezii (Standl.) Bedell, needs further investigation. The current placement of this species 
in Schwartzia apparently balances precariously on the position of its nectaries, at or below the middle of the pedicel rather than near the base of the flower, and on its somewhat elongate pedicels. It too has five stamens and a 3-locular ovary, a combination that is unusual, if not unique (to these three species) in the family. It also has similarly shaped, distinctly petiolate leaves with numerous hypophyllous glands and stalked, rather than sessile nectariferous bracts. In all respects Ruyschia moralesii must certainly be more closely related to Schwartzia jimenezii than to any Costa Rican species now placed in Ruyschia.

Over the years, Schwartzia jimenezii, originally described as a Ruyschia, has been shuttled, somewhat uncomfortably, to other genera (also Norantea), its unusual combination of characters having been contentious, and pointing "toward affinities with species of Ruyschia" (see Bedell 1985: 168). In a recent molecular phylogenetic work (Ward \& Price 2002) that sampled each of the currently recognized genera of Marcgraviaceae, the only robust finding within subfamily Noranteoideae was a sister group relationship between Ruyschia phylladenia Sandwith and Schwartzia costaricensis (Gilg) Bedell, even though Ruyschia has commonly been considered closely related to Soroubea (see de Roon 2005). Neither the currently accepted subdivision of Noranteoideae into six genera nor the older concept with only three, was supported by the molecular study of Ward \& Price (2002). The placement of species in this group has often been problematic, numerous of them having been transferred among two or more of the currently accepted genera. As pointed out by de Roon (2005), recent studies of Marcgraviaceae at the generic level (Ward \& Price 2002, Van Evelghem upublished thesis) have sampled very few species, and decisions concerning taxon realignments should await more indepth studies. With these considerations in mind, and given that Ruyschia is the oldest generic name in subfamily Noranteoideae, one can speculate that further molecular and morphological phylogenetic work in the family is likely to expand the current concept of Ruyschia.

Additional specimens. COSTA RICA. Puntarenas: Cantón de Parrita, Cabeceras del Río Negro, 11001300 m, 27 ene 2002 (bud), J.F. Morales 8295 (CR, INB, MO); Fila Chonta, 1100-1400 m, 27 dic 1997 (bud), J.F. Morales \& R.J. Abarca 6297 (INB, MO). San José: Cantón de Dota, Fila Mona, 1800-1850 m, 25 febr 2001 (bud), J.F. Morales 7575 (CR, INB, MO, NYBG, U); cantón de Tarrazú, ca. 17 km suroeste de
San Marcos de Tarrazú, por el camino a Cerro Cura, 1500 m, 20 dic 2005 (bud, fr), Hammel et al. 23979 (CR, INB); (bud), Hammel et al. 23981 (CR, INB, F, MO); 12 ene 2006 (bud), Hammel et al. 24030 (INB, MO, MICH, USJ); ca. $19 \mathrm{~km}$ de San Marcos de Tarrazú, camino a Quepos, por Londres, $1700 \mathrm{~m}$, 13 ene 2006 (bud), Hammel et al. 24035 (CR, INB, MO, F); del puente de San Marcos $18 \mathrm{~km}$ camino hacia Quepos, propiedad de la familia Garro, 1370 m, 13 ene 2006 (bud), Hammel et al. 24045 (CR, INB, MO, P).

\section{Schwartzia tarrazuensis Hammel, sp. nova}

Haec species nova Schwartzia costaricensi similis, sed nectariis galeiformibus (ad vicem cochleariformibus) glandulisque hypophyllis paucioribus differt; etiam Schwartzia brenesii ob formam nectariorum similis, sed nectario pedicelli basi proximo (ad vicem pedicelli medio) nato, pedicellis longioribus, 68(-10) (ad vicem 4) glandulis hypophyllis in utroque costae lato distincta; a duabus praecedentibus speciebus polline diluto-luteo vel sordido-albo (ad vicem purpureo vel magenteo) dignocenda.

[This species is similar to Schwartzia costaricensis, but differs by its helmet-shaped (versus spoon-shaped) nectaries and by fewer hypophyllous glands; it is also similar to $S$. brenesii for the shape of its nectaries, but differs by the nectary born near the base of the pedicel (versus the middle), by its longer pedicels, and by 6-8(-10) (versus 4) hypophyllous glands on each side of the midrib; the new species differs from both these species by its pollen pale yellow or sordid white (versus purple or magenta)]

TYPE: Costa Rica; San José, cantón de Tarrazú, ca. $13 \mathrm{~km}$ suroeste de San Marcos camino a Quepos, $c a$. $0.8 \mathrm{~km}$ sur del cruce con el camino a Fila San Isidro, sobre camino a Cerro Toro, 1300 m, 14 jul 2005 (fl, fr), Hammel et al. 23715 (holotype: INB, isotypes: COL, CR, F, FR, MICH, MO, P). Figs. 3, 4C.

Shrubby epiphyte or woody liana; stems terete, drying reddish brown. Leaves with the petiolar region $0.1-1 \mathrm{~cm}$, distinctly channeled above, thinlymargined and merging with the \pm abruptly expanded base of the blade; blade $10-14 \times 4-5.5 \mathrm{~cm}$, elliptic to oblong or oblanceolate, drying reddish tan to dark reddish or olive brown, the base \pm symmetrical, abruptly acute to rounded, the apex acute to rounded, mucronate; secondary veins indistinct; hypophyllous glands 6-8(-10) (on each side of the midrib), circular 
to narrowly elliptic, poriform, in a distinct diagonal row on the lamina from the base of the midrib toward the margin at ca. 3/4 the length. Inflorescence an erect raceme, the rachis (including peduncle) $5-9 \mathrm{~cm}$ with 6-12 flowers; pedicels 3-6.5 cm, ascending at mostly $<45^{\circ}$, lacking lenticels. Nectaries green, attached 3$10 \mathrm{~mm}$ from the base of the pedicel, $12-20 \times 5-12$ $\mathrm{mm}$ (at the rim), elongate helmet-shaped, flanged and sometimes with a spur on the rim. Flower buds green, erect, (9)13-16 mm, ovoid, the 2 bracteoles sepaloid, 3.5-6 x 5-7 mm, \pm semicircular, directly subtending and appressed to the sepals; sepals \pm equal, 5.5-8 $\mathrm{x}$ 7-10 mm, broadly semicircular; petals 5 , adaxially greenish red, strongly reflexed at anthesis $13-20 \times 8$ $10 \mathrm{~mm}$, narrowly ovate with an obtuse apex, connate in the basal 1/3. Stamens $12-14$, the filaments bright red, 9-10 $\mathrm{mm}$ at anthesis, flattened, linear-ligulate, \pm adnate to the corolla tube, the anthers pale yellow, 9$10 \mathrm{~mm}$, narrowly triangular, basally sagittate, apically obtuse, introrsly dehiscent, the pollen pale yellow to sordid white, apparently mixed with oil. Ovary 8-10 $\mathrm{mm}$ (including the $2-3 \mathrm{~mm}$ style), \pm obturbinate, 4 - or (rarely and only apically?) 5-loculate, the stigma 4- or (rarely) 5-lobed. Fruits green to reddish green, 18-25 $\mathrm{mm}$, globose-apiculate.

Distribution. Schwartzia tarrazuensis is known only from rain forest at 900-1400 m elevation, on the Pacific slope of Costa Rica's Cordillera de Talamanca.

Etymology. This species is named for the cantón Tarrazú, locality of the type and most other collections.

Discussion. Vegetatively, this species is very similar to Schwartzia costaricensis, with which it is locally sympatric, but differs by its helmet-, rather than spoon-shaped nectaries. It usually also has fewer hypophyllous glands, 6-8 being most common in the new species while $S$. costaricensis usually has more than 10 and as many as 20 , on each half of the blade. In the shape of its nectaries the new species resembles S. brenesii (Stand1.) Bedell, but that species has shorter pedicels (3-4 cm), and the nectary is born near the middle, rather than near the base of each pedicel. Schwartzia brenesii also has only four hypophyllous glands per lamina side. The pollen of both $S$. costaricensis and S. brenesii is purple or magenta while that of the new species is pale yellow to sordid white. The South American S. weddelliana (Baill.) Bedell, thought to be closely related to $S$. brenesii (Bedell 1985), has yellow pollen and helmet-shaped nectaries, but much longer $(2.5-4 \mathrm{~cm})$ nectaries, and more stamens (22-25) than the new species.

Additional specimens. COSTA RICA. Puntarenas: Cantón de Buenos Aires, Altamira de Biolley, 11501350 m, 20 mar 1997 (fl), J. Quesada 1900 (CR, INB, MO); cantón de Parrita, ca. $22 \mathrm{~km}$ suroeste de San Marcos de Tarrazú, rumbo a Fila Chonta, cabeceras del Río Negro y Río Palo Seco, 1200 m, 20 dic 2005 (fl.), Hammel et al. 23996 (INB, USJ). San José: Cantón de Tarrazú, camino a Esquipulas, 1000-1100 m, 5 sept 1996 (fl, fr), Hammel et al. 20413 (CR, INB, MO); camino a Quepos, 900 m, 24 febr 1996 (bud), J.F. Morales \& V. Ureña 5270 (CR, INB, MO).

Acknowledgments. I thank Silvia Troyo for her, as ever, suitable-for-framing and precise illustrations, and Francisco Morales for leading me, once again, to his favorite haunts. This manuscript was finished during a 6 week tenureship as a visiting research scientist at the Muséum National d'Histoire Naturelle, Departement Systématique et Evolution, Herbier National (P). I am very grateful to that institution for providing financial assistantship, as well as to all the curators, librarians and technicians who so graciously facilitated our visit.

\section{Literature Cited}

Bedell, H.G. 1985. A generic revision of Marcgraviaceae, I. The Norantea complex. Unpublished Ph.D. thesis, Univ. Maryland, College Park.

de Roon, A.C. 2005. A new species of Ruyschia (Marcgraviaceae) from the South American Andes. Novon 15: 414-415.

- \& S. Dressler. 1997. New taxa of Norantea Aubl. s.l. (Marcgraviaceae) from Central America and adjacent South America. Bot. Jahrb. Syst. 119: 327-335.

Dressler, S. \& M. Tschapka. 2002. Bird versus bat pollination in the genus Marcgravia and the description of a new species. Bot. Mag. 19: 104114.

Gentry, A.H. \& C.H. Dodson. 1987. Diversity and biogeography of vascular epiphytes. Ann. Missouri Bot. Gard. 74: 205-233.

Van Evelghem, L. 2003. Houtanatomie en Pollenmorfologie van de Marcgraviaceae. Unpublished undergraduate thesis, Institute of Botany and $\mathrm{Mi}$ crobiology, K.U. Leuven.

Ward, N.M. \& R.A. Price. 2002. Phylogenetic relationships of Marcgraviaceae: insights from three chloroplast genes. Syst. Bot. 27: 149-160. 
Zamora, N., B.E. Hammel \& M.H. Grayum. 2004. Novelties. In: Hammel, B.E., M.H. Grayum, C. Herrera \& N. Zamora (eds.). Manual de Plantas de
Costa Rica. Vol. I. Introducción. Monogr. Syst. Bot. Missouri Bot. Gard. 97: 217240 .

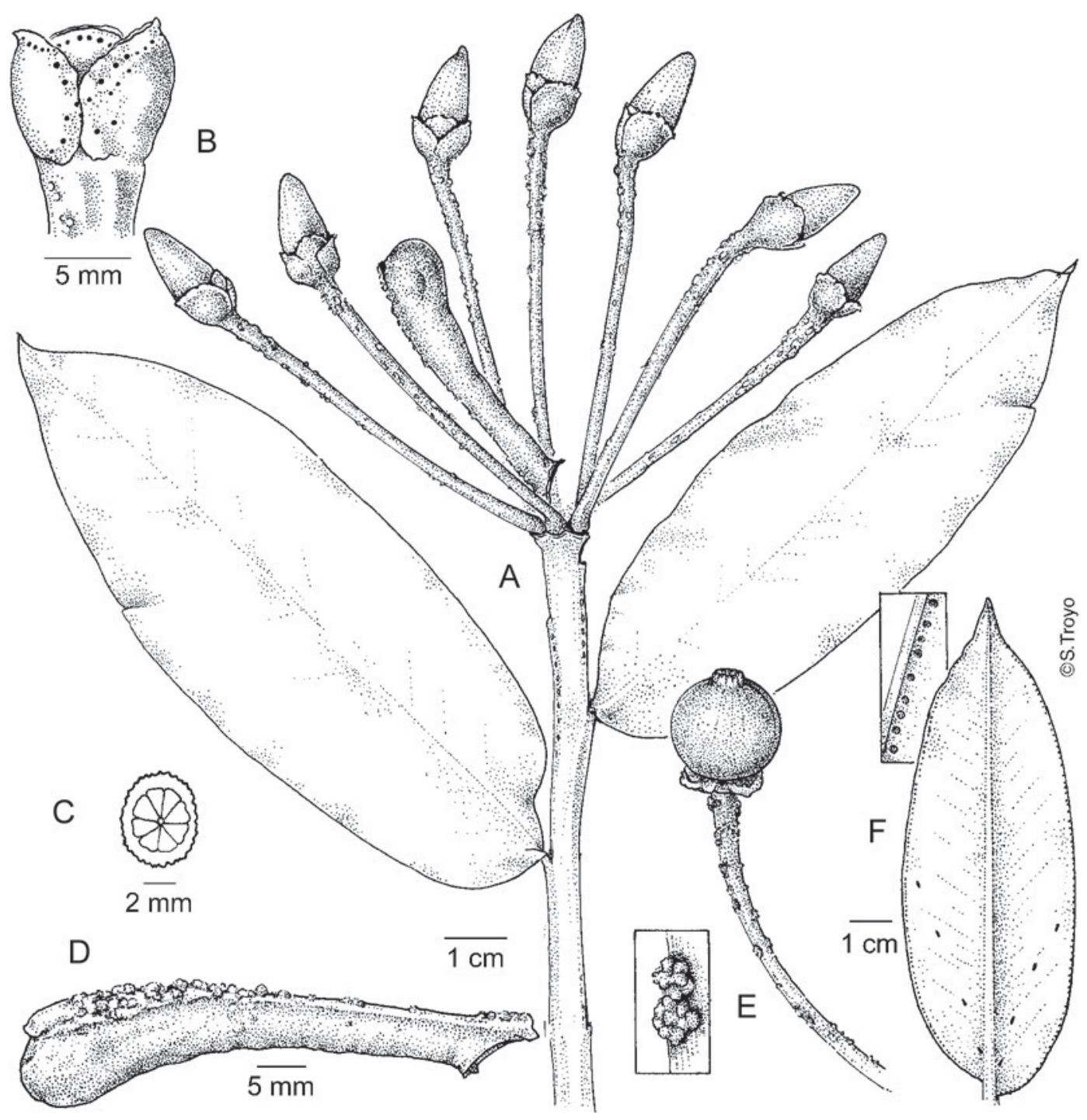

Fig. 1. Marcgravia glandulosomarginata Hammel -A. Branch with mature inflorescence just prior to anthesis. -B. Close-up of calyx showing submarginal rows of glands. -C. Cross section of ovary. -D. Nectary. -E. Fruiting pedicel with detail of lenticels. -F. Lower surface of leaf with detail showing submarginal glands. E from Hammel et al. 20205 (INB), all others from Hammel et al. 23714 (INB). 


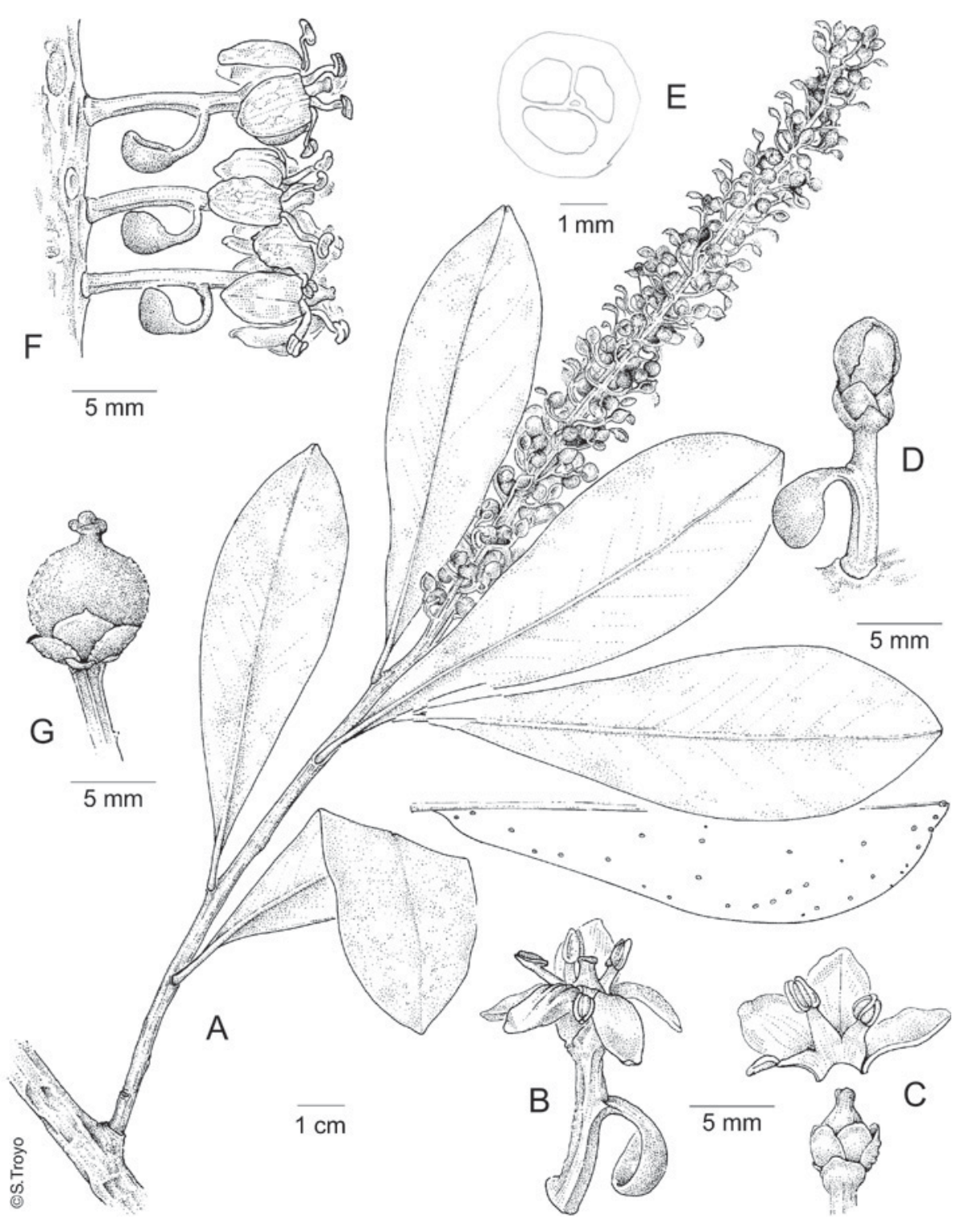

Fig. 2. Ruyschia moralesii Hammel -A. Branch with inflorescence prior to anthesis with detail of leaf lower surface showing hypophyllous glands. -B. Open flower with pedicel and nectary. -C. Ovary with calyx (corolla removed) and partial corolla showing adnate stamens. -D. Mature flower bud. -E. Cross section of ovary. -F. Open flowers at rachis. -G. Fruit. A from Morales 6297 (INB), B-F from Hammel et al. 24095 (INB), G from Hammel et al. 23979 (INB). 


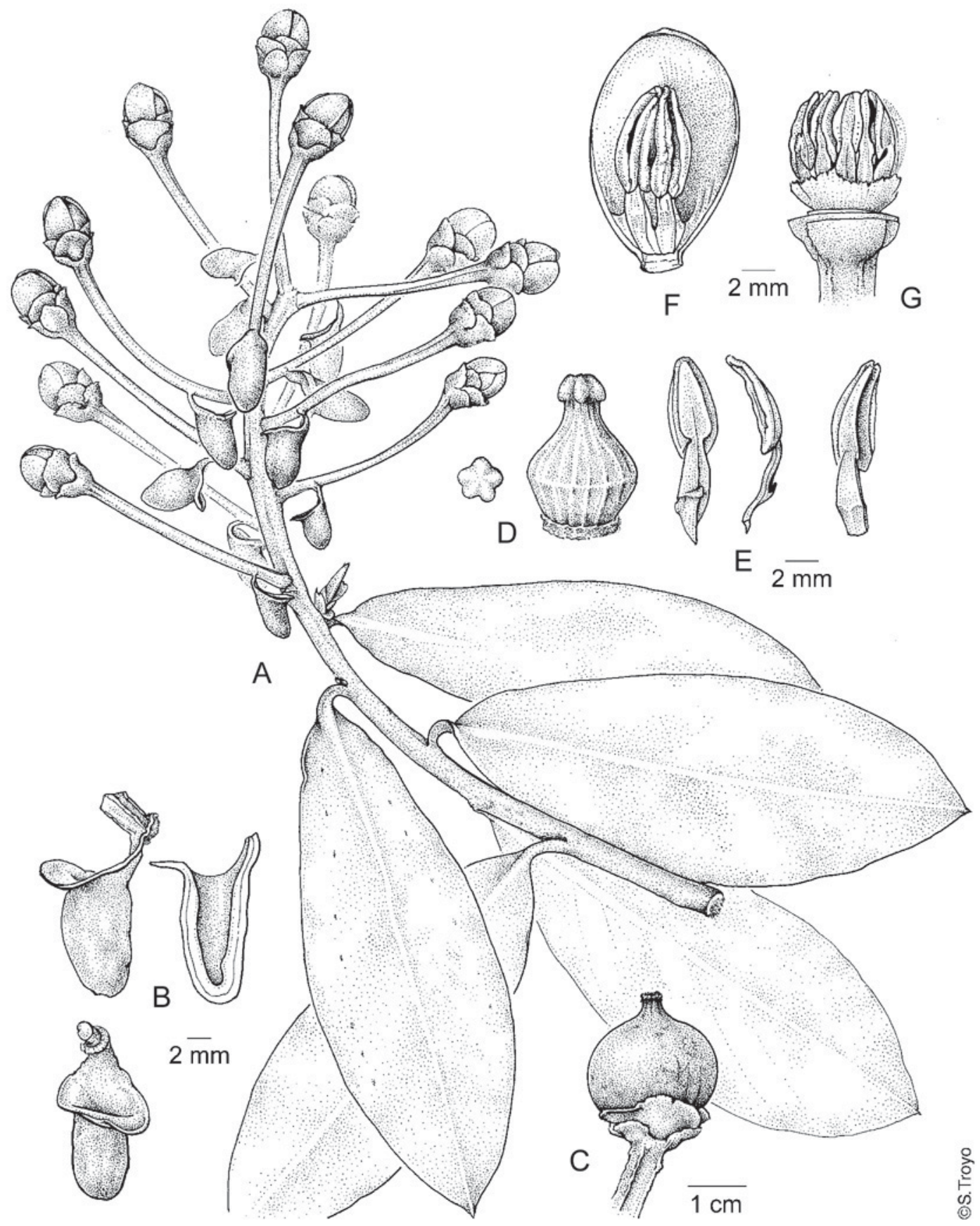

Fig. 3. Schwartzia tarrazuensis Hammel -A. Branch with mature inflorescence just prior to anthesis. -B. Lateral, front and longitudinal section views of nectary. -C. Fruit at top of pedicel. -D. Ovary and top view of stigma. -E. Stamens. -F. Corolla lobe, showing adnate stamens. -G. Mature bud with calyx and corolla lobes removed. B from Quesada 1900 (INB), all others from Hammel et al. 20413 (INB). 


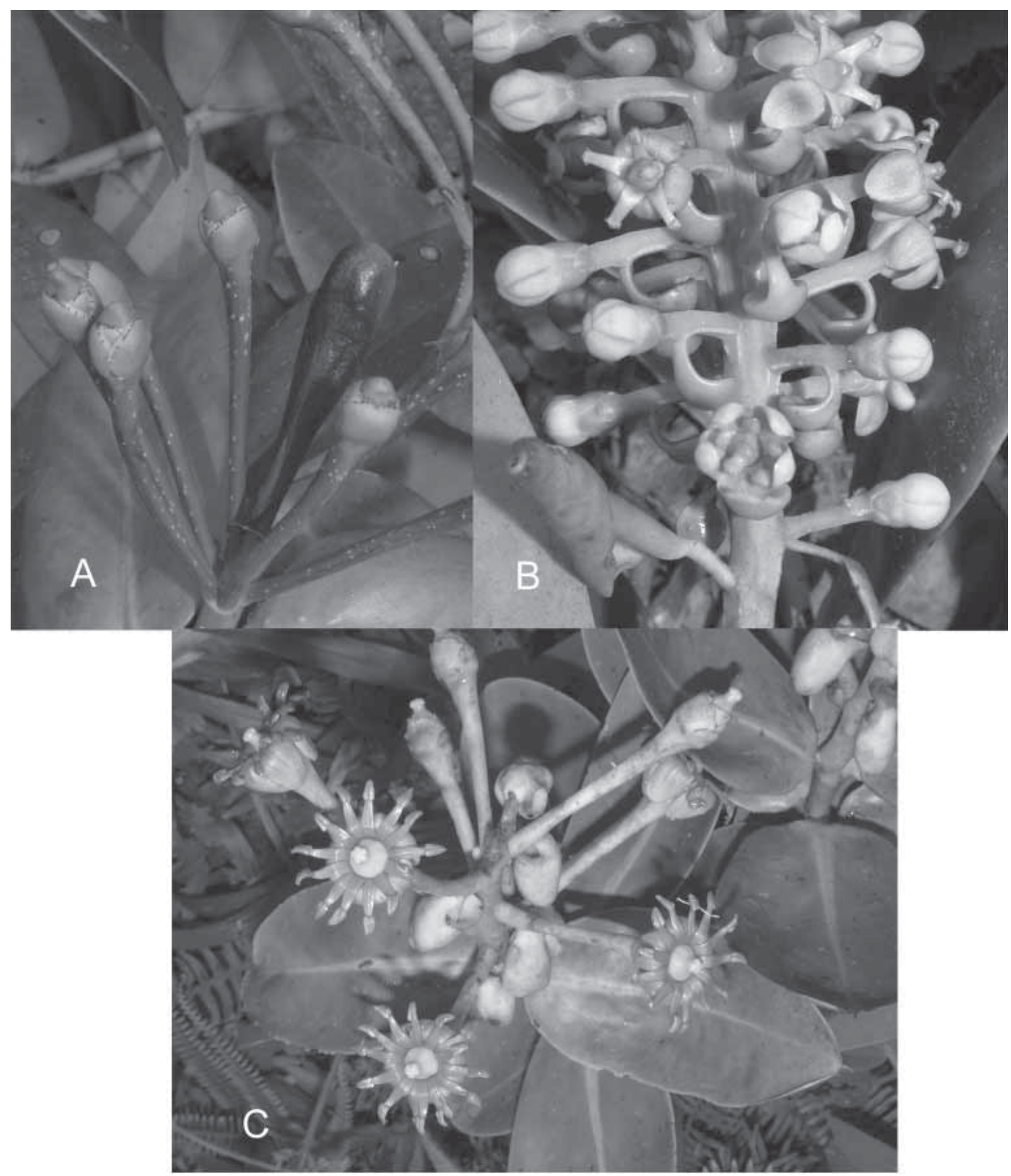

Fig. 4. Three new species of Marcgraviaceae. -A. Marcgravia glandulosomarginata (Hammel et al. 23714). -B. Ruyschia moralesii (Hammel et al. 24095). -C. Schwartzia tarrazuensis (Hammel et al. 23996). 